\title{
Designing a Temple Stay Program Based on the One in Nong Khai Province, Thailand
}

\author{
Thirachaya Maneenetr ${ }^{1} \&$ Thanh Ha $\operatorname{Tran}^{1}$ \\ ${ }^{1}$ Faculty of Management Science, Khon Kaen University, Khon Kaen province 40002, Thailand \\ Correspondence: Thirachaya Maneenetr, Faculty of Management Science, Khon Kaen University, Khon Kaen \\ province 40002, Thailand. E-mail: thirachaya@kku.ac.th
}

$\begin{array}{lcc}\text { Received: February 19, } 2014 & \text { Accepted: March 17, } 2014 & \text { Online Published: June 25, } 2014 \\ \text { doi:10.5539/ass.v10n13p31 } & \text { URL: http://dx.doi.org/10.5539/ass.v10n13p31 }\end{array}$

\begin{abstract}
The aims of this research are to study 1) tourists' opinions and demands for Temple Stay Program (TSP) based on the one in Nong Khai province, Thailand and 2) guidelines to design TSP based on the one in Nong Khai province, Thailand. The Mix method was applied and for the quantitative method, 400 questionnaires were collected and the data was analyzed using mean, standard deviation and Chi-square tests. For the qualitative data, a focus group discussion was organized. The participants included monks, academics, tourism entrepreneurs, involved public organizations and local philosophers who proposed guidelines to design TSP based on the one in Nong Khai province, Thailand.

The results showed that most of the tourists approved of the TSP in Nong Khai province, which has religious activities in tourism to enhance awareness of Thai religious values. Tourists' demands for TSP similar to the one in Nong Khai province, Thailand are at a high level. Guidelines to design TSP based on the one in Nong Khai province, Thailand include 1) establishing an official center of information for TSP in Nong Khai province 2) planning diversity for TSP packages 3) creating diverse and meaningful activities for TSP 4) establishing a training course on local handicrafts or local food for tourists, and 5) expanding roles of monks as guides in Buddhist cultural and local tradition activities.
\end{abstract}

Keywords: religious tourism, temple stay program

\section{Introduction}

Today, religious tourism is closely related with holiday and cultural tourism, especially where the religious sites are prominent significant cultural sites or cultural events (Rinschede, 1992). Temple Stay Program (TSP) is a valuable example consistent with this type of tourism. In Korea, TSP is a cultural experience program which helps tourists understand Buddhism better and creates a positive image for Korean tourism (OECD, 2009). Participating in this program, tourists have a chance to attend the Buddhist ceremonial services and special training programs on local handicraft and food. Tourists can have new experiences either with Korean Buddhism or Korean culture which are in combination called Koreanness (Kaplan, 2010). The successfulness of this program is the best practice for many countries in Asia where Buddhism is one of the major religions such as Thailand, China, Laos and so on (Wang, 2011).

Nong Khai province is a border province which is located in Northeastern, Thailand. This province is rich and diverse with different types of tourism especially tourism related to the Buddhist religion. Ancient historical temples and local festivals with spiritual values attract an increasing number of tourists. At the present, Nong Khai province is emphasizing strategic tourism development based on cultural and local wisdom (NongKhai Provincial Office, 2011). The researchers consider that TSP is valuable and appropriate for religious tourism in Nong Khai province. Based on local culture on Buddhism, TSP applied in Nong Khai province will create new image to attract and enhance awareness of local culture for tourists. Apart from that, Crompton (1979) pointed out that tourists are usually motivated by the match of a destination's major attributes to the travelers' needs. In term of religious tourism, Buddhist temples should be developed promotional strategies designed to increase tourists by creating Buddhist temples as desirable attractions (Choe et al., 2009).Therefore, research questions were raised about tourists' opinions and demands for TSP currently in use in Nong Khai province and what guidelines there should be to design TSP based on the one in Nong Khai province, Thailand. 


\section{Literature Review}

\subsection{Religious Tourism}

Traveling for spiritual or religious purposes is one of the earliest types of tourism in the world. Religious tourism entails people traveling away from their home to places or events of a scared nature and participating in activities, rituals and ceremonies undertaken at the destination (Timothy, 2011). The core activities at religious sites consist of religious services which pay homage to God or prayer ceremonies (Nolan \& Nolan, 1992). But, there are also other activities which motivate tourists to visit religious sites such as learning about the history of the religious site and for aesthetic experiences (Keeling, 2000). Therefore, religious tourism, nowadays, is not only for faith and spiritual values but is also for recreational, educational and cultural purposes (Woodward, 2004).

\subsection{Temple Stay Program (TSP)}

Temple Stay is an innovative program that emerged in 2002 which is opening up Korean Buddhism to the world (Wang, 2011). This is a unique cultural-experience program designed to let people experience the life of Buddhist practitioners at traditional temples which preserve the old history of Korean Buddhism and culture (Kalpan, 2010). Visitors have a chance to sample monastic life amongst the artifacts, treasures and cultural memories housed in Korea's ancient monasteries. The major religious activities are the usual activities such as ceremonial services involving chanting, Zen meditation, tea ceremony and communal Buddhist meal offerings. Other activities related to Buddhist life also are offered, such as martial arts training, lotus lantern making and local handicraft training (OECD, 2009).These activities establish connections among tourists, the local community and Buddhist temples through new experiences in Korea culture, in general. Apart from that, the roles of monks are branded in a new way. The monks have functions at museums and centers of national heritage.

TSP creates a positive image for the Korean tourism destination. This program can be a sustainable tourism, highlighting the three principles in tourism development. It consists of an environmentally-sound, socio-cultural identity and is economical viable (OECD, 2009).

\subsection{Background of Nong Khai Province}

Nong Khai province is located in the upper Northeastern region of Thailand. This province is along the border with Laos PDR by the Mekong River which is across from VienTiane - Laos PDR capital. The first Thai-Lao Friendship Bridge was built to conveniently facilitate trade, transport and travel between Nong Khai province, Thailand and VienTiane, Lao PDR(Nong Khai Provincial Office, 2011).

Religious tourism is a popular type of tourism which focuses on Buddhist temples which are the center of faith and spiritual values in Nong Khai province. There are many well-known temples such as Pho Chai temple, Muang district, and Sri Chom Phu Ongtu temple, Thabo district, Nong Khai province has had an astonishing history with the communities nearby for a hundred years (Piewdang at al., 2013). Paying homage to sacred sites, attending prayer ceremonies or making merit are usually religious activities in tourism in which participants can clear their minds by attending Buddhist lectures (Wong et al, 2013). This province is also well-known for the Naga Fireball, allegedly shot from the Mekong River in northwestern Thailand by a mythical serpent known as Naga. This supernatural phenomenon in the belief of the local community is to greet the return of Lord Buddha from heaven at the end of Buddhist Lent (Cohen, 2007).

\section{Objectives}

1) To study tourists' opinions and demands on TSP based on the one in Nong Khai province, Thailand

2) To study guidelines to design Temple Stay Programs based on the one in Nong Khai province, Thailand

\section{Research Methodology}

To ensure research objectives, the researchers used Mix Methods. The details are described below:

\subsection{To Study Tourists' Perceptions and Demands for TSP Based on the One in Nong Khai Province, Thailand}

To collect quantitate data the researchers selected participants who were Thai tourists and international tourists that traveled to Nong- Khai province. Questionnaires were designed which consisted of three parts: 1) demographic information, including sex, age, educational level, marital status, income and nationality 2) opinions of tourists on TSP based on the one in Nong Khai province, Thailand 3) demands of tourists for a TSP similar to the one in Nong Khai province, Thailand. The questionnaire also used a five point Likert scale and offered five responses: strongly agree, agree, not sure, disagree and strongly disagree. A five point scale was interpreted as shown in table 1 : 
Table 1. Significance of points

\begin{tabular}{cc}
\hline Mean Scores & Levels of Significant \\
\hline $1.00-1.80$ & Lowest \\
$1.81-2.60$ & Low \\
$2.61-3.41$ & Moderate \\
$3.42-4.20$ & High \\
$4.21-5.00$ & Highest \\
\hline
\end{tabular}

According to data from the Department of Tourism (2011) there were 1,163,041 tourists who traveled to Nong Khai province in 2011. The researchers applied Yamane's formula (1973) with a $95 \%$ confidence level to calculate the sampling size as 400 . Data analysis used the mean, standard deviation and Chi-square tests.

in which: $\quad \mathrm{n}=$ sampling size

$$
\mathrm{n}=\frac{N}{1+N e^{2}}
$$

$$
\begin{aligned}
& \mathrm{N}=\text { population size } \\
& \mathrm{e}=\text { level of precision of the confidence level of } 95 \%
\end{aligned}
$$

\subsection{To Study Guidelines to Design TSP Based on the One in Nong Khai Province, Thailand}

In terms of qualitative data, the researchers organized a focus group discussion. There were ten experts including monks, academics, tourism entrepreneurs, involved public organizations and local philosophers. They discussed how to develop appropriate guidelines to improve the potential of religious tourism to incorporate TSP. Data analysis was performed using descriptive analysis.

\section{Research Area}

Nong Khai province which is 3,026.5 square kilometers, is a border province located in the Northeastern region of Thailand. It is only 25 kilometers away from Vien Tiane - Lao PDR capital. It has a population of 510,263 and almost all of the population are Buddhist (NongKhai Provincial Office, 2011).

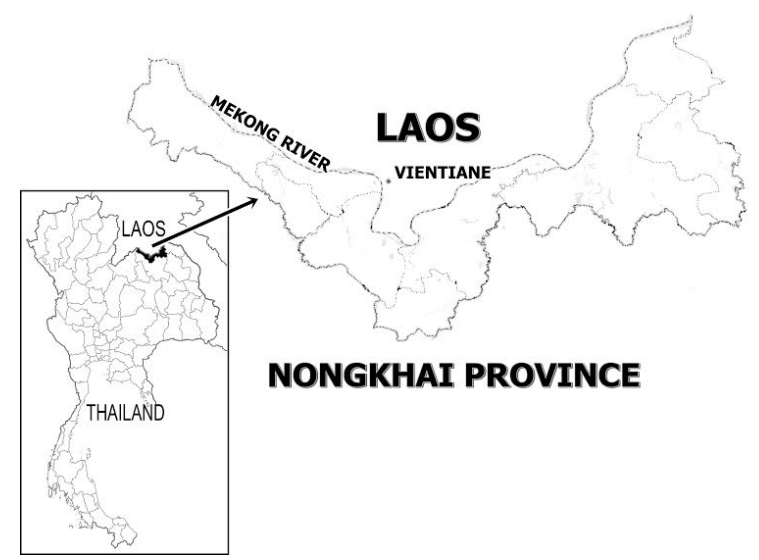

Figure 1. Research area

\section{Research result}

\subsection{Tourists' Opinions and Demands for TSP Based on the One in Nong Khai Province, Thailand}

\subsubsection{Tourists' Opinions on TSP Based on the One in Nong Khai Province, Thailand}

With regards to TSP based on the one in Nong Khai province, an mean of $42.00 \%$ of the tourists defined the meaning of TSP as one that provides a temporary stay for tourists during the practice of religious dharma in accordance with the Monks' presentation and one where they will have a deep experience in Thai Buddhist culture. It was noted that $39.8 \%$ mentioned their main motivation for travelling was to practice meditation and study Buddhist Dharma. Another $39.8 \%$ of the tourists mentioned that antiquity, spirituality and reputation of the temples were the attraction for tourism for TSP. The core element for TSP may be the training in Buddhist 
morality which was mentioned by $29.5 \%$ of the tourists. In particular, $52 \%$ of the tourists thought participating in TSP would bring more charity and spiritual values to themselves. An additional $31 \%$ of the tourists stated that they would like to participate in developing cultural and religious values of Thai people through TSP. Furthermore, $34.2 \%$ of the tourists believe the TSP should be advertised via the Internet to reach a greater number of tourists. Additionally, Nong Khai province is a border province which has a cross-culture between Thai and Lao. Therefore, 38.9\% thought that this was a supporting factor for the TSP in Nong Khai province. Finally, 33.5\% believed that collaboration among stakeholders, temples, and the local community along with involving private and public organizations was the main force to incorporate TSP in Nong Khai province.

6.1.2 Tourist's Demands for TSP Based on the One in Nong Khai Province, Thailand

Table 2 shows the result of tourists' demand for TSP based on the one in Nong Khai province, Thailand.

Table 2.

\begin{tabular}{|c|c|c|c|}
\hline Item & $\overline{\bar{X}}$ & S.D. & Interpretation \\
\hline $\begin{array}{l}\text { Religious tourism products that are unique and which identify the } \\
\text { local culture }\end{array}$ & 4.16 & 0.75 & high \\
\hline Tourists attracted by ancient history of the destination & 3.80 & 0.75 & high \\
\hline Significance of the temple destinations is a fundamental element & 3.84 & 0.71 & high \\
\hline $\begin{array}{l}\text { Diversity of the TSP timeframe such as a } 24 \text {-hour program, a half } \\
\text { day program or an extended } 2-3 \text { days program }\end{array}$ & 3.77 & 0.74 & high \\
\hline $\begin{array}{l}\text { Package with special prices for groups of tourists for example family } \\
\text { groups or elderly groups }\end{array}$ & 3.62 & 0.78 & high \\
\hline Package with special activities to offer on Buddhist holy days & 3.66 & 0.89 & high \\
\hline Diversified and meaningful religious activities in the TSP & 4.18 & 0.75 & high \\
\hline Integrating Buddhist practices with cultural experiences & 3.92 & 0.76 & high \\
\hline Tourists can relax their minds and reflect on their inner self & 3.99 & 0.76 & high \\
\hline $\begin{array}{l}\text { New experiences with the local culture for example: local festivals, } \\
\text { local handicrafts and local food }\end{array}$ & 3.92 & 0.72 & high \\
\hline Safety and security for tourists & 3.88 & 0.85 & high \\
\hline Signposts for temple destinations explicit and numerous & 3.73 & 0.73 & high \\
\hline Public transportation vehicles service for tourists & 3.78 & 0.81 & high \\
\hline $\begin{array}{l}\text { Infrastructures: conditions } \quad \text { to facilitate } \\
\text { (water/electricity/restrooms) }\end{array}$ & 3.86 & 0.76 & high \\
\hline Providing clothing for participants in TSP & 3.82 & 0.79 & high \\
\hline Arranging clean accommodations for tourists in temples & 3.85 & 0.78 & high \\
\hline Religious tourism package prices that are fair & 3.92 & 0.77 & high \\
\hline
\end{tabular}


Table 2 shows the result of tourists' demand for TSP based on the one in Nong Khai province, Thailand (Continued).

Table 2.

\begin{tabular}{|c|c|c|c|}
\hline Item & $\overline{\overline{\mathbf{X}}}$ & S.D. & Interpretation \\
\hline $\begin{array}{l}\text { Clarify portions of the price as accommodation rates, food service } \\
\text { rates and other extra service rates }\end{array}$ & 3.36 & 0.72 & high \\
\hline Diversity of channel distribution such as travel agents or direct sales & 3.88 & 0.75 & high \\
\hline Transparency and flexible reservation processes & 3.92 & 0.76 & high \\
\hline Systematic and creditable TSP planning & 3.90 & 0.81 & high \\
\hline Update information on religious tourism continuously & 3.94 & 0.83 & high \\
\hline $\begin{array}{l}\text { Establishing an official center of information to promote religious } \\
\text { activities and TSP in Nong Khai province }\end{array}$ & 4.13 & 0.70 & high \\
\hline Schedule for planned religious activities & 3.84 & 0.77 & high \\
\hline Etiquette and discipline for participants of TSP in temples & 3.95 & 0.79 & high \\
\hline $\begin{array}{l}\text { Publish books and brochures about Buddhist dharma and local } \\
\text { culture in several languages such as Thai, English, Chinese etc. }\end{array}$ & 3.85 & 0.75 & high \\
\hline $\begin{array}{l}\text { Official website for religious tourism and TSP for Nong Khai } \\
\text { province in Thai - English }\end{array}$ & 4.12 & 0.76 & high \\
\hline $\begin{array}{l}\text { Comprehensive public relations activities especially for international } \\
\text { tourists }\end{array}$ & 4.04 & 0.74 & high \\
\hline Reliable information & 4.08 & 0.77 & high \\
\hline Staffs in religious tourism that are proficient in foreign languages & 3.86 & 0.74 & high \\
\hline $\begin{array}{l}\text { Expanded roles for Monks as guides in Buddhist cultural and local } \\
\text { tradition activities }\end{array}$ & 3.94 & 0.77 & high \\
\hline Government policy to broadly promote TSP & 3.77 & 0.78 & high \\
\hline $\begin{array}{l}\text { Establish a network connection among temples in Nong Khai } \\
\text { province }\end{array}$ & 4.12 & 0.72 & high \\
\hline $\begin{array}{l}\text { Supporting participation from the local community in activities for } \\
\text { TSP }\end{array}$ & 3.99 & 0.74 & high \\
\hline Maintain and preserve temple up-keep continuously & 3.89 & 0.78 & high \\
\hline Requesting and analyzing tourists feedback & 3.82 & 0.83 & high \\
\hline Total & 3.88 & 0.12 & high \\
\hline
\end{tabular}


Table 2 shows tourists' demands for TSP based on the one in Nong Khai province, Thailand. Interpretation of the information is as shown below:

Diversified and meaningful religious activities for TSP was at the high level (mean $=4.18$, S.D. $=.75)$. Religious tourism products that are unique and which identify the local culture was at the high level (mean $=4.16$, S.D. $=.75$ ). Establishing an official center of information to promote religious activities and TSP in Nong Khai province was at the high level $($ mean $=4.13$, S.D. $=.70)$. Official website for religious tourism and TSP for Nong Khai province in Thai - English was at the high level $($ mean $=4.12$, S.D. $=.76)$. Establish a network connection among temples in Nong Khai province was at the high level (mean $=4.12$, S.D. $=.72$ ). Reliable information was at the high level $($ mean $=4.08$, S.D. $=.77)$. Comprehensive public relation activities especially for international tourists was at the high level $($ mean $=4.04$, S.D. $=.74)$.

Tourists attracted by the ancient history of the destination was at the high level (mean $=3.80$, S.D. $=.75$ ). Significance of temple destination is a fundamental element was at the high level (mean $=3.84$, S.D. $=.71$ ). Diversity of the TSP timeframe such as a 24-hour program, a half day program or an extended 2-3 days program was at the high level $($ mean $=3.77$, S.D. $=.74)$. Package with special prices for groups of tourists for example, family groups or elderly groups was at the high level $($ mean $=3.62$, S.D. $=.78)$. Package with special activities to offer on Buddhist holy days was at the high level (mean $=3.66$, S.D. $=.89$ ). Integrating Buddhist practices with cultural experiences was at the high level (mean $=3.92$, S.D. $=.76)$. Tourists can relax their minds and reflect on their inner self was at the high level $($ mean $=3.99$, S.D. $=.76)$. New experiences with the local culture for example: local festivals, local handicrafts and local food was at the high level (mean = 3.92, S.D. $=.72$ ).

Safety and security for tourists was at the high level (mean $=3.88$, S.D. $=.85)$. Signposts of temple destinations explicit and numerous was at the high level (mean $=3.73$, S.D. $=.73$ ). Cleaning up the landscape around the temple destination was at the high level $($ mean $=3.83$, S.D. $=.73)$. Public transportation vehicles service for tourists was at the high level $($ mean $=3.78$, S.D. $=.81)$. Infrastructures: conditions to facilitate tourists (water/electricity/restrooms) was at the high level (mean $=3.86$, S.D. $=.76)$. Providing clothing for participants in TSP was at the high level $($ mean $=3.82$, S.D. $=.79)$. Arranging clean accommodations for tourists in temples was at the high level (mean $=3.85$, S.D. $=.78)$.

Religious tourism package prices that are fair was at the high level (mean $=3.92$, S.D. $=.77$ ). Clarify portions of price as accommodation rates, food service rates and other extra service rates was at the high level (mean $=3.36$, S.D. $=.75)$. Diversity of channel distribution such as travel agents or direct sales was at the high level (mean = 3.88, S.D. $=.74)$. Transparency and flexible reservation processes was at the high level $($ mean $=3.92$, S.D. $=.76)$ Systematic and creditable TSP planning was at the high level $($ mean $=3.90$, S.D. $=.81)$. Update information on religious tourism continuously was at the high level $($ mean $=3.94$, S.D. $=.83)$. Schedule for planned religious activities was at the high level $($ mean $=3.84$, S.D. $=.77)$. Etiquette and discipline for participants of TSP in temples was at the high level (mean $=3.95$, S.D. $=.79$ ). Publish books and brochures about Buddhist dharma and local culture in several languages such as Thai, English, Chinese etc. was at the high level (mean $=3.85$, S.D $=.75$ ).

Staffs in religious tourism that are proficient in foreign languages was at the high level (mean $=3.86$, S.D. $=.74$ ). Expanded roles for Monks as guides in Buddhist cultural and local tradition activities was at the high level $($ mean $=3.94$, S.D. $=.77)$. Government policy to broadly promote TSP was at the high level (mean = 3.77, S.D. $=.78$ ). Supporting participation from the local community in activities for TSP was at the high level (mean $=$ 3.99, S.D. $=.74$ ). Maintain and preserve temple up-keep continuously was at the high level (mean $=3.89$, S.D. $=.78)$. Requesting and analyzing tourists feedback was at the high level $($ mean $=3.89$, S.D. $=.78)$.

\subsection{Guidelines to Design TSP Based on the One in Nong Khai Province, Thailand}

Data is collected from a focus group discussion. Ten experts including monks, academics, tourism entrepreneurs, involved public organizations and local philosophers who discussed and proposed strategic management to design a TSP similar to the one in Nong Khai, as shown below:

In Nong Khai province, the attributes of religious tourism destinations have enough potential to grow and develop widely and deeply. TSP is a hopeful form of tourism development based on culture and Buddhism, particularly in Nong Khai and in Thailand in general. Religious tourism is a form of tourism where people travel to visit places of religious significance (Hanandeh, 2013) and cultural significance of destinations (Egreri et al., 2012). Supporting tourism to religious sites not only provides new experiences to tourists (especially international tourists) through interacting with local society but also improves the quality of local life through economic benefit (Rotherham, 2007). On the other hand TSP will create pull factors in religious tourism in Nong Khai province in which Thai religion, local cultural, local wisdom are attributes to fascinate both religious and 
non-religious tourists with new experiences in Thai Buddhist culture. Therefore, guidelines to design TSP based on the one in Nong Khai province, Thailand should focus on the aspects as below:

\subsubsection{Establishing an Official Center of Information for TSP in Nong Khai Province}

Tourism information centers are one major information resource for tourists both before arrival at their destination and during their visit (Shi, 2006). Websites have had a profound effect on information dissemination in the tourism domain (Buhalis, 2003).

In terms of the province, religious organizations and tourism development organizations are the two crucial parts necessary to establish an official center of information for TSP in Nong Khai province. This center plays an important role in planning, advertising and controlling the quality of TSP. An official website for TSP should be established by the official center of information for TSP in Nong Khai province. This website would provide information about temples, package deals for TSP reliability and up-to-date information. The official website for TSP should be presented in Thai, English and other languages to have extensive appeal to international tourists.

\subsubsection{Planning Diversity for TSP Packages}

Sánchez et al. (2006) stated that symbolic valuation was made of the tourism package, which fundamentally demonstrated the importance of tourists' interaction in tourism activities. Tourists travel to religious sites with various motivations such as religious practice, recreation or cultural experiences. Thus, TSP in Nong Khai province should be separated into a lot of packages such as a 24 hour program, a half -day program, a 1-2 day program, or an extended 3-4 day program. Facilities should be made available to tourists to provide such things as clothing, accommodation and food depending on the period of time of the program.

Apart from that, activities in TSP should be arranged from a basic level to a high level experience in Buddhist religion, for example, tours around historical temples in Nong Khai city, Buddhist chanting ceremonies, and afterward meditation practice.

\subsubsection{Creating Meaningful Activities for TSP}

In Nong Khai province, the population is mainly Buddhist which reflects on the local lifestyle and culture. Activities in TSP should represent the local living culture in the way of Buddhist wisdom to help tourists understand and to enhance their awareness of local culture. For example, the Naga fireball festival is based on the supernatural phenomenon of a fireball allegedly shot from the Mekong River. This festival reflects on the Buddhist belief that the local community is to greet the return of Lord Buddha from heaven at the end of Buddhist Lent. This promotes an integrating of Buddhist practice with the local cultural experience. It is consistent with Richard (2009) states that during travelling, activities allow tourists to experience a destination deeply and respect on cultural differences.

\subsubsection{Establish a Training Course of Local Handicraft or Local Food for Tourists}

Cultural activities also attract tourists, especially international tourists. A training course about local handicrafts and local food will provide a unique experience for tourists and a close connection between tourists and the local community. As Nason (1984) states that the production of handicraft and local souvenir will enhance perception and awareness of local cultures. Training courses could be organized for making Krathongs (decorating lanterns with bamboo leaves) during Loy Krathong festival, making Thai chili paste, and making Thai papaya salad should be considered as a part of TSP activities.

\subsubsection{Expanding Roles of Monks as Guides in Buddhist Cultural and Local Tradition Activities}

Temple stay's meaning is implied by the name - a temporary stay in a temple. Therefore, Monks play an important role in the introduction of Buddhism to tourists. It is consistent with Kaplan (2010) who Monks seem to be eclectic museum and centers of national heritage. The Monks can be guides of temple history, Buddhist Dharma and Buddhist practice. They can introduce tourists to self-reflection through Buddhist activities. The monks are also the center of local traditions and cultural wisdom; helping to preserve and disseminate these from the local people to tourists.

There are fundamental guidelines to incorporate TSP in Nong Khai province. TSP is a long term plan intended to promote religious tourism, in particular, and cultural tourism, in general, in Nong Khai province. It requires step - by - step strategic management in order to achieve success. However, the core of TSP lies in support from the government, religious organizations and public and private organizations to succeed (Wang, 2011). 


\section{Conclusion}

In this study, the researchers investigated the problems of tourists' perception and demands for a TSP based on the one in Nong Khai province, Thailand and proposed guidelines to design TSP similar to the one in Nong Khai province, Thailand. The results showed that based on the one in Nong Khai province, TSP incorporates religious activities in tourism to enhance awareness of Thai religious values. Guidelines to design TSP based on the one in Nong Khai province, Thailand include 1) establishing an official center of information for TSP in Nong Khai province 2) planning diversity for TSP packages 3) creating meaningful activities for TSP 4) establishing a training course of local handicraft or local food for tourists, and 5) expanding the role of monks as guides in Buddhist cultural and local tradition activities.

\section{References}

Buhalis, D. (2003). eTourism. United Kingdom: Prentice-Hall.

Choe, J., Blazey, M., \& Mitas, O. (2013). Motivations of non-Buddhists visiting Buddhist Temples. Current Issues in Tourism. http://dx.doi.org/10.1080/13683500.2013.771627.

Cohen, E. (2007). The "Postmodernization" of a Mythical Event: Naga Fireballs on the Mekong River. Tourism Culture \& Communication, 7(3), 169-181. http://dx.doi.org/10.3727/109830407782212493

Crompton, J. L. (1979). Motivations for pleasure vacation. Annals of Tourism Research, 6(4), 408-424. http://dx.doi.org/10.1016/0160-7383(79)90004-5

Department of Tourism. (2011). Summary Situation of Tourism in the Northeast, Thailand. Retrieved from http://www.tourism.go.th/2010/upload/filecenter/file/stat_2554/Final2554/northeast1.pdf

Egreri, I., Bayram, B., \& Kara, F. (2012). Tourism at Religious Sites: A Case from Mardin, Turkey. Geographica Timisiensis, 21(1), 5-15. Retrieved from http://www.geografie.uvt.ro/old/cercetare/publicatii/ geographica/abstracte/Geographica2012-1/ARTICOL_1_EGRESI.pdf

Hanandeh, A. E. (2013). Quantifying the carbon footprint of religious tourism: The case of Hajj. Journal of Cleaner Production, 52(1), 53-60. http://dx.doi.org/10.1016/j.jclepro.2013.03.009

Kaplan, U. (2010). Images of Monasticism: The Temple Stay Program and the Re-branding of Korean Buddhist Temples. Korean Studies, 34, 127-146. http://dx.doi.org/10.1353/ks.2010.0010

Keeling, A. (2000). Church Tourism: Providing a ministry of welcome to visitors. In A. Ryland (Ed.), Insights (pp. A-13). London: English Tourism Council.

Nason, J. (1984). Tourism, Handicrafts and ethnic identity in Micronesia. Annals of Tourism Research, 11, 421-449.

Nolan, M., \& Nolan, S. (1992). Religious sites as tourism attractions in Europe. Annals of Tourism Research, 19, 68-78. http://dx.doi.org/10.1016/0160-7383(92)90107-Z

NongKhai Provincial Office. (2011). Basic Information of Nong Khai province. Retrieved from http://123.242.162.3/nongkhai/files/714034641doc-24-06-54.doc

OECD. (2009). Chapter 8: Temple Stay Programme, Korea. The Impact of Culture on Tourism (pp. 115-127). Retrieved from http://www.oecd.org/korea/42040158.pdf

Piewdang, S., Mekkamol, P., \& Untachai, S. (2013). Measuring Spiritual Tourism Management in Community: A Case Study of Sri Chom Phu Ongtu Temple, Thabo district, Nongkhai province, Thailand. Procedia Social and Behavioral Sciences, 88, 96-107. http://dx.doi.org/10.1016/j.sbspro.2013.08.485

Richards, G. (2009). Tourism development trajectories - From culture to creativity? Tourism Research and Marketing, Barcelona. Paper presented to the Asia-Pacific Creativity Forum on Culture and Tourism, Jeju Island, Republic of Korea, 3-5 June 2009. Retrieved from http://www.tram-research.com/atlas/ APC\%20Paper\%20Greg\%20Richards.PDF

Rinschede, G. (1992). Forms of religious tourism. Annals of Tourism Research, 19(1), 51-67. http://dx.doi.org/10.1016/0160-7383(92)90106-Y

Rotherham, I. D. (2007). Sustaining Tourism Infrastructures for Religious Tourists and Pilgrims within the UK. In R. Raj, \& N. D. Morpet (Eds.), Religious Tourism and Pilgrimage Festivals (pp. 64-77). Wallingford, Oxfordshire: CABI Publishing.

Sánchez, J., Callarisa, L., Rodríguez, R. M., \& Moliner, M. A. (2006). Perceived value of the purchase of a tourism product. Tourism Management, 27(3), 394-409. http://dx.doi.org/10.1016/j.tourman.2004.11.007 
Shi, Y. (2006). The accessibility of Queensland visitor information centres' websites. Tourism Management, 27(5), 829-841.

Timothy, D. J. (2011). Cultural Heritage and Tourism: An Introduction. Bristol; Buffalo, Channel View Publication.

Wang, W. (2011). Explore the Phenomenon of Buddhist Temple Stay in South Korea for Tourists. UNLV Theses/Dissertations/Professional Papers/Capstone. Paper 1074. Retrieved from http://digitalscholarship. unlv.edu/thesesdissertations/1074

Wong, C. U. I., McIntosh, A., \& Ryan, C. (2013). Buddhism and Tourism Perception of the Monastic Community at Pu-Tou-Shan, China. Annals of Tourism Research, 40, 213-234. http://dx.doi.org/10.1016/ j.annals.2012.09.004

Woodward, S. C. (2004). Faith and tourism: planning tourism in relation to places of worship. Tourism and Hospitality Planning \& Development, 1(2), 173-186. http://dx.doi.org /10.1080/1479053042000251089

Yamane, T. (1973). Statistic: An introductory analysis (3rd ed.). New York: Harper and Row Publication.

\section{Copyrights}

Copyright for this article is retained by the author(s), with first publication rights granted to the journal.

This is an open-access article distributed under the terms and conditions of the Creative Commons Attribution license (http://creativecommons.org/licenses/by/3.0/). 